Benioff short- and long-period vertical seismometers in addition to the two Milne-Shaw instruments. The Canadian Broadcasting Corporation now transmits the Dominion Observatory noon time signals over the entire Canadian network, so that accurate timing is possible at all the seismograph stations. Seismograms from all the Canadian stations are now sent to Ottawa for analysis and interpretation, and the results published in the Monthly Bulletin issued by the Dominion Observatory.

\section{Scientific Equipment and the Laboratory}

IN the Nivoc Supplement (edited and published by Messrs. W. and J. George, Ltd.-F. E. Becker and Co., London and Birmingham, No. 17, July 1940) the importance of up-to-date scientific equipment in, and correct planning of, a laboratory is stressed. Facilities for reséarch and scientific control and testing have become an essential part of manufacturing organizations. Particularly is this so in the case of companies supplying materials to the aircraft industry, since the progress of aeronautical development is largely dependent upon the development of improved materials, both for air-frames and engines, and a very high standard of material testing and inspection has been set up. It is therefore necessary for the supplier of materials to maintain adequate research and testing establishments staffed with competent personnel. Messrs. George have recently equipped new laboratories for High Duty Alloys, Ltd. New buildings, designed by Colonel A. L. Abbott, house eleven different laboratories and departments in addition to a library and lecture theatre, and are considered to be an outstanding example of modern laboratory planning and furnishing. Teak bench tops are strongly advocated for general use. A brief note is given on the Burma teak forest and methods of exploitation, the information having been made accessible by the High Commissioner for India.

\section{Cancer Research}

IN order to ensure opportunities for the publication of the scientific results of cancer research, a group of representatives of interested organizations are to co-operate in making possible a new journal Cancer Research, to be devoted to articles and abstracts of articles having to do with cancer research. This journal is sponsored by the American Association for C'ancer Research, the Anna Fuller Fund, the International Cancer Research Foundation, and the Jane Coffin Childs Memorial Fund for Medical Research. It is hoped to start publication with the issue of January, 1941. Manuscripts should be addressed to the Secretary of the Editorial Committee, 333 Cedar Street, New Haven, Connecticut. Subscriptions are now being received at the office of the Business Manager, American Oncologic Hospital, 33rd Street and Powelton Avenue, Philadelphia. Annual subscription, one volume of twelve issues per year, will be: to members of the American Association for Cancer Research, five dollars; to non-members, seven dollars.

\section{Announcements}

As president of the Royal Society, Sir Henry Dale becomes ex officio a member of the War Cabinet Scientific Advisory Committee under the chairmanship of Lord Hankey. Sir William Bragg, at the special request of Lord Hankey, will remain a member of the Committee until next October, when he will have completed a year of service with it.

Dr. J. Hurchinson, keeper of museums of botany, Royal Botanic Gardens, Kew, has been awarded the Loder Rhododendron Cup of the Royal Horticultural Society.

Prof. W. M. SMaRT, regius professor of astronomy in the University of Glasgow, has been appointed Halley Lecturer at Oxford for 1941.

Prof. G. Pólya, formerly professor of higher mathematics in the Technical High School, Zurich, has joined the Department of Mathematics in Brown University.

Is moving the second reading in the House of Commons of the War Damage Bill, Sir Kingsley Wood, Chancellor of the Exchequer, announced that whereas the general charge on buildings, etc., would be at the rate of $2 s$. in the pound on the annual value, that on institutions for the advancement of education, science or research would be at the rate of $8 d$. in the pound. Agricultural properties are to pay $6 d$. in the pound, and hospitals and churches are exempted from payment.

THE title of professor of physics as applied to medicine in the University of London has been conferred on Dr. W. V. Mayneord in respect of the post held by him at the Royal Cancer Hospital (Free). The following have been awarded the degree of D.Sc. : Mr. J. H. Burgoyne (Imperial College of Science and Technology); Mr. S. L. Cowan (University College); Mr. C. H. Johnson (University College) ; Mr. R. W. B. Pearse (Imperial College of Science and Technology); Mr. M. J. D. White (University College) ; Mr. J. G. King, an external student. The Sir John William Lubbock Memorial Prize in mathematics for 1940 has been awarded to Mr. M. G. Pimputkar, of University College.

Applications for fellowships under the FinneyHowell Research Foundation, Inc., for 1941 must be made by January 1. This Foundation was provided for in the will of the late Dr. George Walker of Baltimore for the support of "research work into the cause or causes and the treatment of cancer". Fellowships carrying an annual stipend of 2,000 dollars are awarded for a period of one year, with the possibility of renewal up to three years; when deemed wise by the Board of Directors, special grants of limited sums may be made to support the work carried on under a fellowship. The address of the Foundation is 1211 Cathedral Street, Baltimore, Maryland.

IN NATURE of December 7, p. 743, reference was made to the jubilee of the City and South London Railway. We regret to learn, however, that the details of reconstruction work given in the second paragraph refer to the Waterloo and City Railway. 